\title{
In Depth Analysis of the Dually Listed Companies in Hong Kong and China Stock Markets Prior and Posterior to the Global Financial Turmoil
}

\author{
Olivia T. K. Choi ${ }^{1}$, Heung Wong ${ }^{2}$, Cedric K. F. Yiu ${ }^{2} \&$ Marco Yu \\ ${ }^{1}$ Department of Statistics and Actuarial Science, University of Hong Kong, Pokfulam, Hong Kong, China \\ ${ }^{2}$ Department of Applied Mathematics, The Hong Kong Polytechnic University, Hunghom, Kowloon, Hong \\ Kong, China \\ Correspondence: Cedric K.F. Yiu, Department of Applied Mathematics, The Hong Kong Polytechnic University, \\ Hunghom, Kowloon, Hong Kong, China. E-mail: macyiu@polyu.edu.hk
}

\author{
Received: May 28, $2013 \quad$ Accepted: August 8, $2013 \quad$ Online Published: September 26, 2013 \\ doi:10.5539/ijef.v5n10p100 URL: http://dx.doi.org/10.5539/ijef.v5n10p100
}

\begin{abstract}
Given the close economic and political activities in Hong Kong and China, we expect the share prices of the companies co-listed in the two financial markets to go in tandem. In this paper, we re-visit the study of co-integration of companies listed in Hong Kong (H-shares) and in the Shanghai Stock Exchanges (A-shares), employing the Vector Error Correction Models (VECM) and Johansen Trace Test prior and posterior to the global financial crisis. Our results showed consistent and significant co-integration among these A- and Hshares co-listed in these markets.
\end{abstract}

Keywords: Hong Kong and China stock markets, A and H shares, co-integration

\section{Introduction}

In the 16th Central Committee of the Communist Party of China (CPC) held in autumn 2005, the Chinese leaders approved the proposals of formulating the 11th Five-year Plan for National Economy and Social Development to further improve the economic and financial development. Albeit the global economic downturn, the Chinese stocks markets have been developing fast. The Hong Kong Stock Exchange (SEHK) had 1,477 listed companies with a combined market capitalization of US\$ 2.2 trillion, ranked fifth largest in the world. Market capitalization of the Shanghai Stock Exchange and Shenzhen Stock Exchange totaled US\$ 4.5 trillion, ranked second largest behind New York Stock Exchange in the world.

Given the close economic relationship and rapid growth between the Mainland China and Hong Kong, we expect the share prices of the co-listing companies shall go in tandem. Numerous studies (MacDonald \& Taylor, 1991; Kasa, 1992; Corhay et al., 1993) had been approving the long-term stocks co-movements among some developed equity markets.

$\mathrm{Su}$, Chong and Yan (2007) also found considerable evidences that supported the presence of co-movement of share price cross-listed in Hong Kong and Shanghai between 2002 and 2004. The existence of long-term financial co-integration of cross-listed shares has importance implication on Efficient Market Hypothesis (Toda \& Philips 1993) as well as portfolio diversification (Taylor \& Tonks, 1989; Kasa 1992).

At the time of the U.S. subprime problem that spread for the global financial crisis between 2007 and 2009. The MSCI World Index had fallen $42 \%$ in 2008 , the worst year on record. The world banking system has undergone a long period of tremendous and painful challenge.

Applying the structural break analysis (Perron \& Yabu 2009), we observed a significant structural break occurred for the stocks co-listing in Hong Kong and Shanghai Stock Exchanges between April 2007 and January 2009. We attempt to re-examine the existence of shares co-movement of the A-share (listed in Shanghai Stock Exchanges) and H-share (listed in Hong Kong Stock Exchange) prior and posterior to the financial turmoil in our study. We employed the Vector Error Correction Models (VECM) introduced by Granger (1981), Engle and Granger (1987), as well as the Johansen Trace Test (Johansen, 1998), to test the levels of co-integration among these companies from January 2004 to December 2011, excluding the structural-break period. Our results 
showed a stronger and more persistent co-integration among the A- $\mathrm{H}$ - share performance in the posterior period and the results provided considerable evidence further approved that the public companies, with identical business models and equity valuation, listing in different stock exchanges shall have the same price performance in a long run.

\section{Hong Kong and Shanghai Financial Markets Background}

The A shares were denominated in RMB and opened to Chinese Mainland investors as well as selected overseas institutional investors. The two major stock exchanges were Shanghai Stock Exchanges (SHS) and Shenzhen Stock Exchanges (SHZ), which opened on December 26, 1990 and April 11, 1991, respectively. Since the adoption of the Open Door policy and economic reform in late 1980s, the mainland financial markets had been growing fast. As of end of 2007, there were 1,530 companies went public and listed in these exchanges, market capitalization, as measured by the numbers of issue shares and market price, had grown to RMB 35.8 trillion (US\$4.8 trillion), ranked second largest in the world after the New York Stock Exchange.

The H shares were listed in Hong Kong Stock Exchange (SEHK), they were issued by mainland-incorporated firms in Hong Kong and accessible to global investors. The first H-share was listed in Hong Kong Stock Exchange (SEHK) after the co-signed Chinese-Hong Kong Memorandum of Regulatory Co-operation in June 1993. By the end of July 2008, there were 42 Mainland companies offering H-shares, giving Hong Kong and global investors some access to many major Mainland economic sectors. The $\mathrm{H}$-share market capitalization had grown to HK\$9.4 billion (US\$ 1.2 billion) in Hong Kong Stock Exchange, representing 56.9\% of the Hong Kong stock market.

As capital was not allowed to flow freely into and out of the China mainland due to the currency policy, the Aand $\mathrm{H}$ - shares were not convertible although each unit represented the same voting right at the listed firm. The A shares lagged the performance of the $\mathrm{H}$ - shares in early 2000s as the mainland market was plagued by corporate scandals and insider trading problems. However, as the Chinese government targeted to strengthen its financial markets and to improve market transparency in its economic reform, the stocks market started to soar in mid 2000s. Their valuations were now higher than their Hong Kong counterparts.

On June 29, 2007, the Hong Kong Hang Seng Index Services Limited announced the introduction of the Hang Seng China Premium A-H Index to help investors tracking the performance of the 31 major Chinese companies dual listed in SHS/SHZ and SEHK. The index measured the weighted average premium (or discount) of A-share prices to $\mathrm{H}$-share prices of the index constituents. The higher the index, the higher premium A- share is trading compared to H-shares. The following figure showed in January 2008, the A-share was trading up to $200 \%$ premium to their counterparts in Hong Kong. As the global equities market plummet, the gap narrowed in late 2010 and 2011.

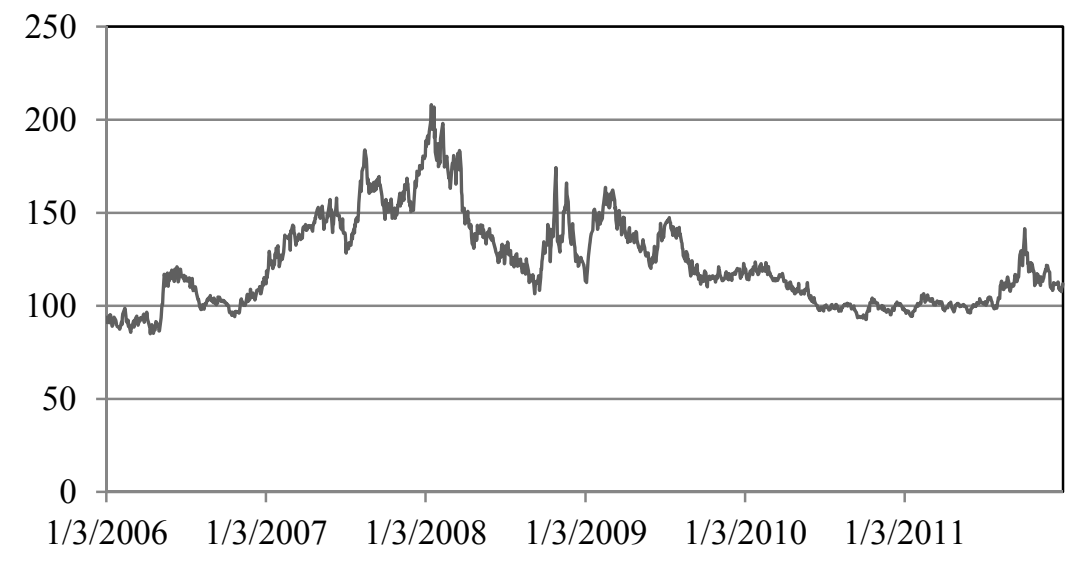

Figure 1. Hang Seng China A-H premium index

\section{Data Description and Methodology}

Despite the shares premium, we expect the levels of movement and fluctuation of these shares are moving in tandem. In this study, we examined the major 35 companies cross-listed in Hong Kong Stock Exchange and Shanghai Stock Exchange. These Chinese companies represented the significant sectors in China including 
Financials/Banks, Transportation/Logistics, Utilities, Materials, Retails, and Commercial Services. We collected the transaction and financial data including daily share prices, market capitalizations, trading volume and indices data from Bloomberg. In order to adjust for the currency effects as A- and H- shares were denominated in RMB and Hong Kong dollars, respectively, we converted all trading data to Hong Kong dollars for analytical purpose.

To investigate the strength of the common stochastic trend within the co-listed shares, we employed the concept of co-integration relation with Vector Error Correction Models (VECM) (Granger, 1981; Engle \& Granger 1987) and performed the Johansen Trace Test (Johansen, 1988) to evaluate the strength of co-integration relation. Note that it was found in Lee and Tse (1996) that the effect of heteroskedasticity does not seriously affect the test results.

\subsection{Vector Error Correction Models}

We modeled each pair of the co-listed shares price in form of a $\operatorname{VECM}(p-1)$

$$
\Delta \tilde{z_{t}}=\Pi \tilde{z_{t-1}}+\Gamma_{1} \Delta \tilde{z_{t-1}}+\ldots+\Gamma_{p-1} \Delta \tilde{z_{t-p+1}}+\mu+\tilde{e_{t}}
$$

where $\tilde{z}_{t}=\left(Z_{1, t}, Z_{2, t}\right)^{\prime}$ represent the $\log$ price of $\mathrm{H}$ and A shares, $\Delta \tilde{z_{t}}=\left(\tilde{z_{t}}-\tilde{z_{t-1}}\right)$ is the first difference of the $\log$ price, $\mu$ is a $(2 \times 1)$ coefficient vector, $\Pi$ and $\Gamma_{i}$ 's are $(2 \times 2)$ coefficient matrices, and $\tilde{e}_{t}=\left(e_{1, t}, e_{2, t}\right)^{\prime}$ is an unobservable zero-mean independent white noise error.

By substituting $\Pi=-\left(I-A_{1}-\ldots-A_{p}\right)$ and $\Gamma_{\mathrm{i}}=-\left(A_{i+1}+\ldots+A_{p}\right)$ for $i=1,2, \ldots, p-1$, the model can be written as a pth order Vector Autoregressive model $\operatorname{VAR}(p)$ as below,

$$
\tilde{z}_{t}=A_{1} \tilde{z}_{t}+\ldots+A_{p} \tilde{z}_{t-p}+\mu+\tilde{e}_{t}
$$

Assuming the process $\tilde{z}_{t}$ is stationary after taking the first difference (i.e. $\tilde{z}_{t} \sim I(1)$ ), then all terms in equation (1) are $I(0)$ except $\Pi \tilde{z}_{t-1}$. Given that the left hand sides of equation (1) are both $I(0), \Pi \tilde{z}_{t-1}$ must be $I(0)$ as well. Hence, it contains linear combinations of the variables that are $I(0)$. As a result, $\Pi$ is singular (i.e. $\operatorname{rank}(\Pi)=1$ ) containing the co-integration relation and is often referred as the long-run factor, where $\Gamma_{i}$ 's are often referred as the short-run factor.

We further imposed the deterministic component, $\mu$, which only affects the long-run factor by restricting $\mu=\Pi \mu_{0}$, then our VECM can be re-written as

$$
\begin{aligned}
\Delta \tilde{z_{t}} & =\Pi\left(\tilde{z_{t-1}}+\mu_{0}\right)+\Gamma_{1} \Delta \tilde{z_{t-1}}+\ldots+\Gamma_{p-1} \Delta \tilde{z_{t-p+1}}+\tilde{e_{t}} \\
& =\Pi^{*} \tilde{z}_{t-1}^{*}+\Gamma_{1} \Delta \tilde{z_{t-1}}+\ldots+\Gamma_{p-1} \Delta \tilde{\Delta t-p+1}+\tilde{e_{t}}
\end{aligned}
$$

where $\Pi^{*}=[\Pi: \mu]$ and $\tilde{z}_{t-1}^{*}=\left[\tilde{z}_{t-1}^{\prime}: 1\right]^{\prime}$.

The order $p$ is determined by the order specification criteria Akaike's Information Criterion (AIC) (Akaike, 1974), Hannan-Quinn Criterion (HQ) (Hannan \& Quinn, 1979), Schwarz Criterion (SC) (Schwarz, 1978). From our analysis, the 3 criteria suggested the same order selection $(\operatorname{VECM}(1))$ for most of the sampled shares. Although AIC suggested a higher order for a few shares, we do choose the VECM(1) to analysis the 4 shares as both HQ and SC still consistently suggested a VECM(1).

\subsection{Johansen Trace Test}

To evaluate the strength of the co-integration relation, we employed the Johansen trace test statistic to test the hypothesis $H_{0}(r): \operatorname{rank}(\Pi)=r$ against $H_{1}(r): \operatorname{rank}(\Pi)>r$ (Johansen, 1994). The Johansen trace test statistic is of the form

$$
-T \sum_{j=r+1}^{p} \log \left(1-\lambda_{j}\right)
$$

such that $\lambda_{j}$ are the descending ordered eigenvalues solving the generalized eigenvalue problem

$$
\operatorname{det}\left(\lambda S_{11}-S_{01}^{\prime} S_{00}^{-1} S_{01}\right)=0
$$

where

$$
\begin{gathered}
S_{00}=T^{-1} \Delta Z\left(I-X^{\prime}\left(X X^{\prime}\right)^{-1} X\right) \Delta Z^{\prime}, \\
S_{01}=T^{-1} \Delta Z\left(I-X^{\prime}\left(X X^{\prime}\right)^{-1} X\right) Z^{\prime},
\end{gathered}
$$




$$
S_{11}=T^{-1} Z\left(I-X^{\prime}\left(X X^{\prime}\right)^{-1} X\right) Z^{\prime},
$$

$\Delta Z=\left[\Delta \tilde{z}_{1}, \ldots, \Delta \tilde{z}_{T}\right], Z=\left[\tilde{z}_{0}^{*}, \ldots, \tilde{z}_{T-1}^{*}\right]$, and $X=\left[X_{0}, \ldots, X_{T-1}\right]$ with $X_{t-1}=\left[\Delta \tilde{z}_{t-1}^{\prime}, \ldots, \Delta \tilde{z}_{t-p+1}^{\prime}\right]^{\prime}$.

To test the existence of cointegration, we perform the Johansen trace test with the hypothesis $H_{0}(0): \operatorname{rank}(\Pi)=$ 0 and conclude that the $\mathrm{H}$ and A shares are cointegrated if the null hypothesis $H_{0}(0)$ is rejected at the $5 \%$ level. Details about the VECM, estimation and testing can be retrieved from Johansen (1995), and Kratzig and Lutkepohl (2004).

\subsection{Structural Break Determination}

In the midst of 2007 to early 2008, the global financial markets were experiencing an unstable economic condition while the global banking sector collapsed, triggered by the demise of Lehman Brothers. Since the existence of structural break will affect the validity of our co-integrating rank tests results, structural break analysis was performed before the investigation of cointegration.

\section{a. Regression model with structural breaks}

Perron and Yabu (2009) considered the structural break in time series with integrated or stationary noise component of the form

$$
\begin{gathered}
y_{t}=\mu_{0}+\beta_{0} t+\left(\mu_{1}+\beta_{1} t\right) \times 1\left(t>T_{1}\right)+u_{t}, \\
u_{t}=\alpha u_{t-1}+e_{t}
\end{gathered}
$$

for $t=1, \ldots, T_{1}, \ldots, T$ and $\alpha \in(-1,1]$, where $e_{t} \sim \operatorname{iid}\left(0, \sigma^{2}\right), T_{1}$ represents the time of structural break.

In this analysis, we considered the one-time break in the intercept model:

$$
\Delta z_{t}=\mu_{0}+\mu_{1} \times 1\left(t>T_{1}\right)+u_{t}
$$

\section{b. Testing for structural break and estimating the break point}

To determine the significance of break point with unknown break date, the Exp test is employed. We performed our analysis from the null hypothesis of no structural break versus the alternative of a single break. If the null hypothesis is rejected, the break point is estimated by minimizing the sum of squared residuals from the regression model.

\section{c. Structural break determination for the Hong Kong and China stock markets}

Based on the methodology described above, we performed the structural break analysis for the Hong Kong and China indices, and the 35 co-listed stocks sampled, approving most of the occurrence of structural breaking period existed around April 2007 to January 2009 (Table 1). To avoid the noises created due to the unsteady share price performance owing to the Global financial recession, we divided our analysis into two sub-periods from January 2004 to March 2007 and February 2009 to December 2011, respectively.

Table 1. Break points summary based on the Exp test

\begin{tabular}{cccl}
\hline H Stock & Break Point & A Stock & \multicolumn{1}{c}{ Break Point } \\
\hline HSCEI & $2007-10-30$ & SHCOMP & $2007-10-16^{* * *}$ \\
DJIA & $2009-03-09^{*}$ & SZCOMP & $2008-01-15^{* *}$ \\
AGS & $2007-10-16$ & AGS & $2007-10-18^{* *}$ \\
AHC & $2007-10-11$ & AHC & $2007-10-11$ \\
AHE & $2008-11-25$ & AHE & $2007-09-05$ \\
AIR & $2008-10-27$ & AIR & $2008-11-06^{* *}$ \\
BNS & $2008-10-29{ }^{* *}$ & BNS & $2008-11-04^{*}$ \\
BOC & $2009-01-12^{*}$ & BOC & $2007-11-02^{*}$ \\
BPM & $2008-10-27^{*}$ & BPM & $2008-11-04^{* *}$ \\
CEA & $2007-09-21^{*}$ & CEA & $2007-09-21^{* *}$ \\
CMB & $2008-10-27$ & CMB & $2007-10-31^{* * *}$ \\
CPC & $2007-10-15$ & CPC & $2007-11-02^{* *}$ \\
CSA & $2007-09-21^{*}$ & CSA & $2008-01-02^{* *}$ \\
CSD & $2008-04-23$ & CSD & $2008-01-11^{*}$ \\
DFE & $2007-10-02$ & DFE & $2008-01-14$ \\
GZP & $2008-11-07$ & GZP & $2008-11-07^{* * *}$ \\
GZS & $2007-10-18^{* *}$ & GZS & $2007-10-16^{* * *}$ \\
\hline
\end{tabular}




\begin{tabular}{clll}
\hline HDP & $2007-10-18$ & HDP & $2007-09-18$ \\
HKE & $2010-04-2{ }^{*}$ & HKE & $2005-07-08^{*}$ \\
HNP & $2007-10-18$ & HNP & $2007-09-24$ \\
ICB & $2009-03-03$ & ICB & $2007-11-01^{*}$ \\
JSE & $2007-10-02{ }^{* *}$ & JSE & $2008-01-14$ \\
JWT & $2008-10-27^{*}$ & JWT & $2007-08-27$ \\
JXC & $2008-10-27$ & JXC & $2007-10-12^{*}$ \\
KMM & $2007-10-2{ }^{* *}$ & KMM & $2008-01-10^{*}$ \\
LYG & $2009-08-05$ & LYG & $2008-11-04{ }^{*}$ \\
MIS & $2008-10-27$ & MIS & $2007-09-17^{*}$ \\
NEE & $2008-10-27$ & NEE & $2007-05-29$ \\
NJP & $2008-10-27$ & NJP & $2005-07-18$ \\
SSP & $2008-10-27$ & SSP & $2007-10-18{ }^{*}$ \\
SXP & $2008-10-27$ & SXP & $2005-07-19$ \\
SZE & $2007-10-09$ & SZE & $2007-09-28{ }^{*}$ \\
TDB & $2008-01-09$ & TDB & $2007-09-28$ \\
TJC & $2008-10-27{ }^{*}$ & TJC & $2008-04-08$ \\
YCM & $2008-10-27$ & YCM & $2007-10-16$ \\
YZC & $2008-10-27$ & YZC & $2007-05-15{ }^{*}$ \\
ZTE & $2008-10-27$ & ZTE & $2008-10-27$ \\
\hline
\end{tabular}

Remark: The rejection of $\mathrm{H} 0$ : no additional break is remarked by ${ }^{*},{ }^{* *}$ and ${ }^{* * *}$ at $10 \%, 5 \%$ and $1 \%$ sig. level, respectively. The A share of GZP experienced a trade suspension after 2011-11-07.

\section{Analysis of Results}

Between 2004 and 2006, Hong Kong H-share and Chinese A-share experienced an upward buying momentum together with the U.S. market. The prolonged rising market indices were fuelled by the over-valued housing sector and the subprime market on the backdrop of the low interest rates and loose monetary environment. The H-share index (HSCEI) rose from 4,763 in January 2005 to 20,081 in October 2007; whereas the Shanghai Composite Index rose from 1,242 to 5,954 in the same period (Figure 2).
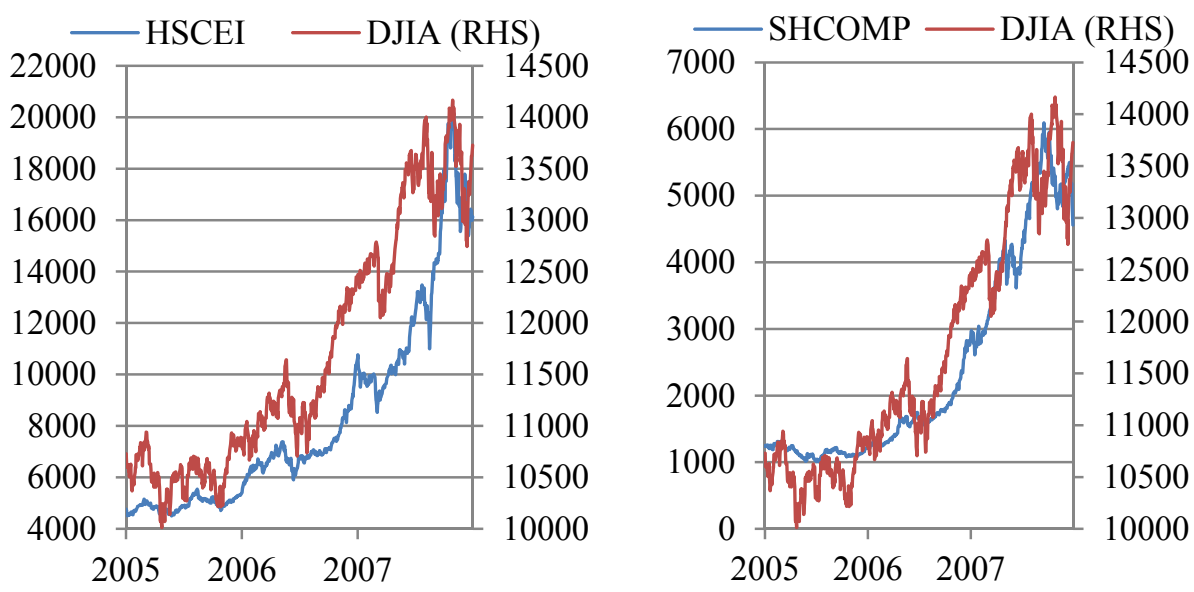

Figure 2. H-share and Chinese A-share experienced an upward buying momentum with DJIA

The global financial markets had undergone a tremendous challenge during the U.S. subprime crisis and credit crunch in 2007, the start of the phenomenon was pinpointed on 9 August 2007 when bad news spread from French bank BNP Paribas triggered sharp rise in the cost of credit, and made the global financial world realize how serious the situation was.

Between 2004 and 2006, U.S. interest rates rose from 1.0\% to 5.35\%, triggering a slowdown in the housing market. Homeowners, many of whom could only barely afford their mortgage payments when interest rates were low, began to default on their mortgages. The impacts of these defaults were spread across the financial 
system as many of the mortgages were bundled up and sold to banks and other investors. The financial system was shaken with increasing liquidity risks when the panicking investors called for their money. The global equities had fallen more than $40 \%$ in 2008, the worst year on MSCI World index record. Our structural break analysis approved the existence of structural break between April 2007 and January 2009, owing to the unstable share prices performance.

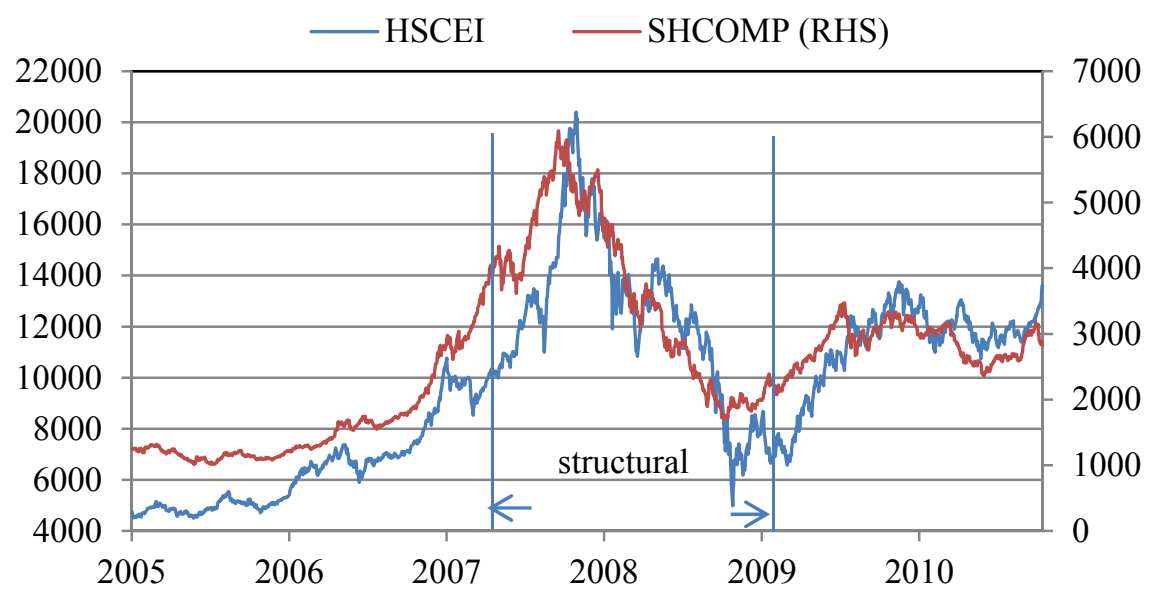

Figure 3. Hang Seng H-Share index vs. Shanghai composite index

We extended our analysis on share co-integration posterior to the financial crisis from February 2009 to December 2011, and observed a persistent co-movement of share performance among the H- and A- shares. Figure 3 showed the performance of HSCEI and SHCOMP from January 2005 to December 2011. After the peak of HSCEI closing at 20,081 in Oct 2007 and SHCOMP at 5,954, both indices plummet and corrected by more than fourfold.

After the structural break period in figure 4, both indices had stabilized at 10,000s and 3,500 levels, respectively. The $\mathrm{H}$ - and $\mathrm{A}$ - shares managed to re-gain their buying momentum and thus resulted in a closer and higher co-integration of shares movement.

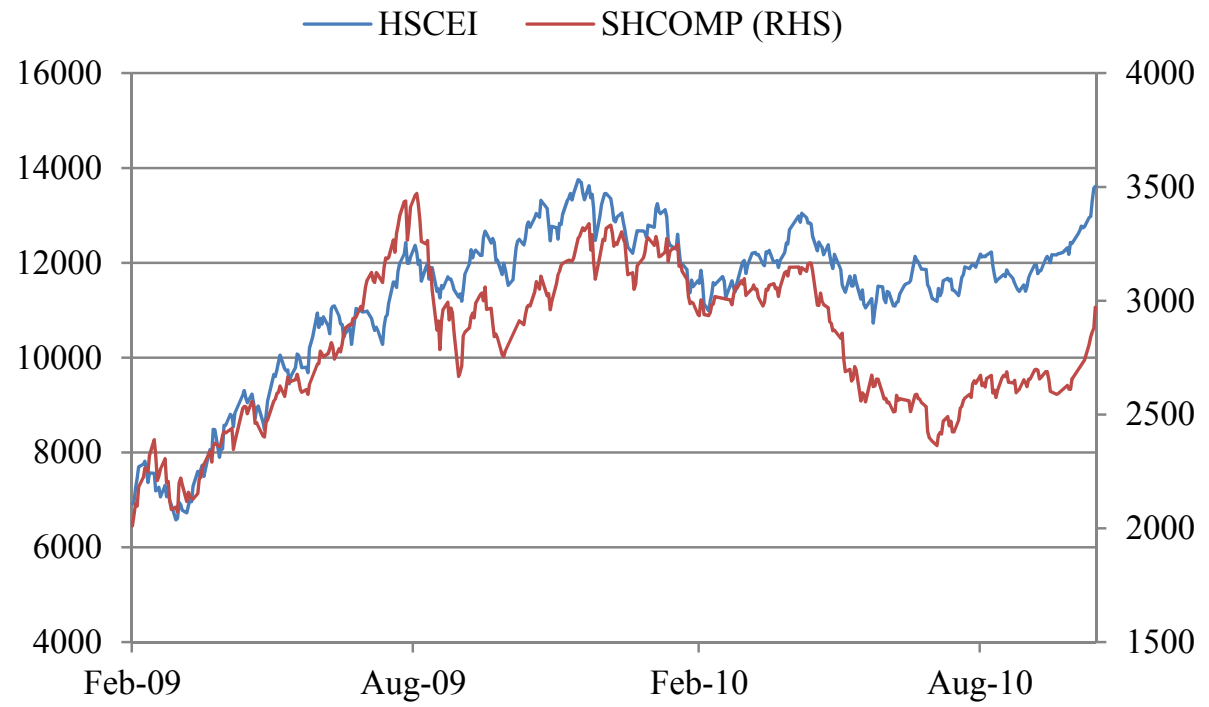

Figure 4. Performance of H-share index and Shanghai Composite Index (RHS) 


\subsection{Micro Analysis}

We extended our study on stock levels as shown in table 2 . If we only consider stock co-movement is significant at $1 \%$ and $5 \%$ levels, we found that 33 out of 35 co-listing stocks under our screen showed significant co-integration after the global financial crisis, compared to 23 out of 35 prior to the turmoil. A simple test of proportions has a statistics 3.2, which shows the difference is very significant. It was an important finding that majority of the co-listed companies showed an emerging shares movement. At the time of uncertain global economic outlook, international funds were injecting into these Chinese companies and hence the shares move in tandem.

Table 2. Johansen trace test statistics for dually listed A- H- share pre- \& post- structural break

\begin{tabular}{|c|c|c|c|c|c|c|}
\hline \multirow[b]{2}{*}{1} & \multirow{2}{*}{$\frac{\text { Code }}{\text { AHE }}$} & \multirow{2}{*}{$\begin{array}{c}\text { Stocks } \\
\text { Anhui Express Way }\end{array}$} & \multicolumn{2}{|c|}{$\begin{array}{c}\text { Pre-structural } \\
\text { break }\end{array}$} & \multicolumn{2}{|c|}{$\begin{array}{l}\text { Post-structural } \\
\text { break }\end{array}$} \\
\hline & & & 10.227 & & 18.022 & \\
\hline 2 & BPM & Beiren Printing Machinery & 10.040 & & 19.526 & ${ }^{* * *}$ \\
\hline 3 & CEA & China East Air & 11.978 & & 20.805 & ${ }^{* * * *}$ \\
\hline 4 & GZP & Guangzhou Pharma & 9.050 & & 13.489 & ${ }^{* *}$ \\
\hline 5 & GZS & Guangzhou Shipyard International & 8.591 & & 13.516 & ${ }^{* *}$ \\
\hline 6 & HDP & Huadian Power & 7.458 & & 25.215 & ${ }^{* * * *}$ \\
\hline 7 & HKE & Hisense Kelon Electrical & 9.831 & & 23.124 & ${ }^{* * *}$ \\
\hline 8 & NJP & Nanjing Panda & 9.677 & & 36.180 & ${ }^{* * *}$ \\
\hline 9 & $\mathrm{TJC}$ & Tianjin Capital & 7.729 & & 27.270 & ${ }^{* * * *}$ \\
\hline 10 & JWT & Jingwei Textile & 12.136 & & 13.180 & ${ }^{* *}$ \\
\hline 11 & LYG & Luoyang Glass & 11.109 & & 13.342 & ${ }^{* *}$ \\
\hline 12 & YCM & Yanzhou Coal Mining & 10.977 & & 12.835 & ** \\
\hline 13 & $\mathrm{AHC}$ & Anhui Conch & 27.519 & *** & 23.953 & *** \\
\hline 14 & BNS & Beijing North Star & 20.516 & *** & 26.696 & $* * *$ \\
\hline 15 & BOC & Bank of China & 16.753 & **** & 18.380 & **** \\
\hline 16 & $\mathrm{CMB}$ & China Merchants Bank & 16.419 & $* * *$ & 19.836 & *** \\
\hline 17 & $\mathrm{CPC}$ & China Petroleum \& Chemical & 27.555 & ${ }^{* * *}$ & 21.552 & ${ }^{* * *}$ \\
\hline 18 & CSA & China South Air & 14.697 & $* *$ & 12.659 & ${ }^{* *}$ \\
\hline 19 & CSD & China Ship Dev & 16.302 & ** & 14.114 & ** \\
\hline 20 & HNP & Huaneng Power & 24.351 & $* * *$ & 27.524 & ${ }^{* * *}$ \\
\hline 21 & JSE & Jiangsu Expressway & 34.697 & *** & 17.581 & ${ }^{* * *}$ \\
\hline 22 & KMM & Kunming Machine & 15.699 & ${ }^{* *}$ & 13.523 & ${ }^{* *}$ \\
\hline 23 & SSP & Sinopec Shanghai Petrochemical & 12.433 & $* *$ & 14.237 & ${ }^{* *}$ \\
\hline 24 & TDB & Tsingtao Brew & 16.437 & **** & 47.285 & ${ }^{* * *}$ \\
\hline 25 & YZC & Yizheng Chem & 18.889 & ${ }^{* * * *}$ & 19.191 & ${ }^{* * *}$ \\
\hline 26 & AGS & Angang Steel & 18.791 & ${ }^{* * *}$ & 14.599 & ${ }^{* *}$ \\
\hline 27 & MIS & Maanshan Iron \& Steel & 18.317 & $* * *$ & 15.862 & ${ }^{* *}$ \\
\hline 28 & SXP & Shandong Xinhua Pharmaceutical & 18.577 & $* * *$ & 13.218 & ** \\
\hline 29 & AIR & Air China & 12.686 & ${ }^{* *}$ & 24.878 & ${ }^{* * *}$ \\
\hline 30 & DFE & Dongfang Elec & 15.080 & "** & 25.211 & ${ }^{* * *}$ \\
\hline 31 & $\mathrm{JXC}$ & Jiangxi Copper & 13.961 & ** & 25.066 & ${ }^{* * *}$ \\
\hline 32 & SZE & Shenzhen Express & 12.538 & ** & 26.867 & ${ }^{* * *}$ \\
\hline 33 & ZTE & ZTE & 16.141 & ** & 25.770 & ${ }^{* * *}$ \\
\hline 34 & ICB\# & Indust'l and Commercial Bank of China & 18.117 & **** & 12.079 & \\
\hline 35 & NEE & Northeast Electric Development & 27.777 & *** & 11.693 & \\
\hline
\end{tabular}

Remark: The rejection of H0: $\mathrm{r}=0$ is remarked by $* *$ and $* * *$ at $5 \%$ and $1 \%$ sig. level, respectively. Pre: Pre-structural break period Jan 2004 - Apr 2007. Post: Post-structural break February 2009 - Dec 2011.

ICB\#: listed on SEHK and SHS on October 27, 2006.

Considering Northeast Electric Development with market capitalization of HK\$500 million as a small-cap company and immaterial in global investors' portfolio, Industrial and Commercial Bank of China (ICB) was the only stock showing a significant weakening co-integration between its $\mathrm{A}$ - and $\mathrm{H}$ - counterparts posterior to the financial breakout. According to official statistics, ICB was the largest bank in the world by profit and 
market capitalization, it was simultaneously listed on both the Hong Kong Stock Exchange and Shanghai Stock Exchange on 27 October 2006. It was the world's largest IPO at that time valued at US\$21.9 billion.

ICB's Hong Kong listed shares fell in mid July 2011 after its strategic stakeholders, Temasek, Singapore sovereign wealth investor, and Goldman Sachs sold down part of their shares. It was triggered by a report from Moody's on local government debt was much larger than previously estimated. China's banking sector had been trading on fear, especially after China's banks have been putting aside more money to prepare for rising losses from loans to local governments. According to a report by China Construction Bank, mainland lenders had already put aside their expected non-performing loans (NPLs) as reserves.

The sell-off of the China Construction Bank by its strategic shareholders, Temasek and Goldman Sachs led a sudden drop in its share prices in Hong Kong and as a consequence a lower co-integration between the A- and Hshares was observed. However, we expect the share co-movement was resumed, excluding this incident, in a long run (Figure 5).

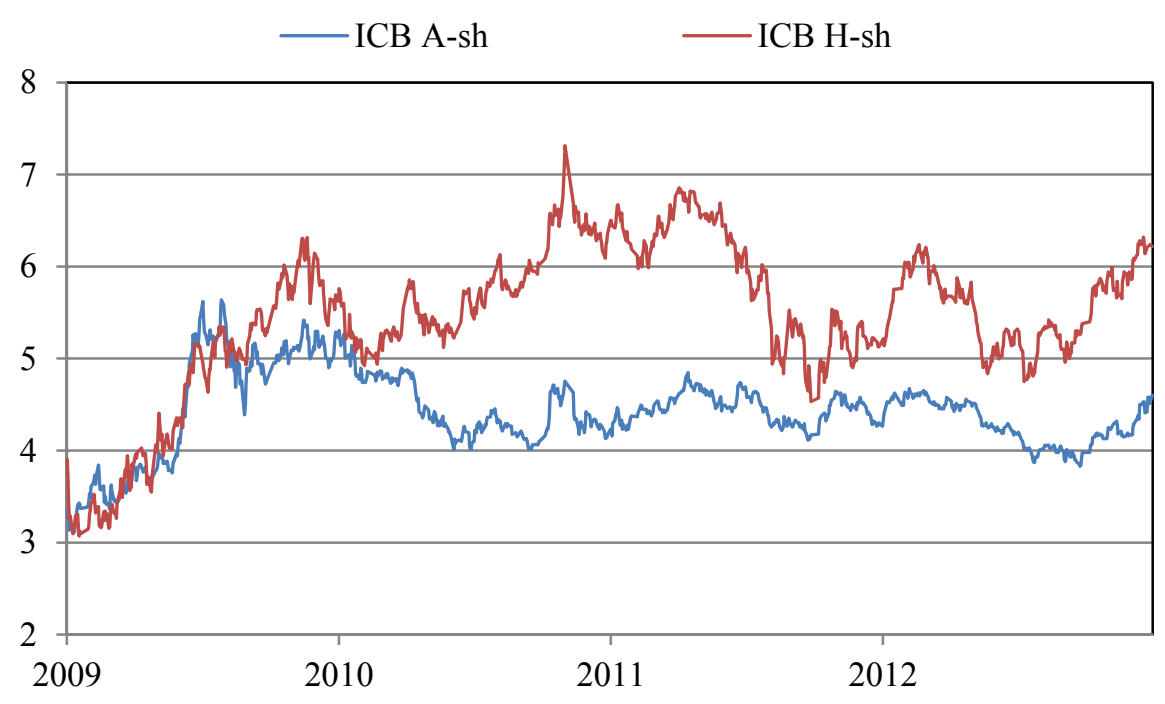

Figure 5. ICB H-share vs A-share performance

\subsection{Sector Analysis}

Among the co-integrating dually listed companies, we observed the "Materials" sector performed consistently in both pre- and post- structural break periods (Table 3). They were mainly the mid-cap companies with market capitalization ranging from HK\$ 8.2 billion to HK\$ 24.8 billion, and trading at a similar ranking within the Aand $\mathrm{H}$ - shares universe in 2007 and 2009. We used the shares' market capitalization value as a measurement to rank the trading sentiments towards the stocks. For example, Anhui Conch A-share was ranked 16th 2007 and remained on the 16th in 2009. It indicated Anhui Conch was not heavy sold down or subscribed by investors during the period. Whereas its H-share was ascended from 18th to 12th after the financial breakout and its market capitalization was increased due to more investors' buying interests. Nonetheless, as our Johansen test indicated, the $\mathrm{A}$ - and $\mathrm{H}$ - shares still showed significant co-integration. 
Table 3. "Materials" sector showed persistent co-integration between A- H- shares

\begin{tabular}{|c|c|c|c|c|c|c|c|c|c|c|}
\hline & \multirow[b]{3}{*}{ Name } & & & \multicolumn{7}{|c|}{ Constituent ranking } \\
\hline & & \multirow{2}{*}{\multicolumn{2}{|c|}{ Pre }} & & & \multicolumn{2}{|c|}{ A-share } & \multicolumn{2}{|c|}{$\mathrm{H}$-share } & \multirow{2}{*}{$\begin{array}{l}\text { Mkt cap } \\
\text { (HK\$bn) }\end{array}$} \\
\hline & & & & \multicolumn{2}{|c|}{ Post } & 2007 & 2009 & 2007 & 2009 & \\
\hline 1 & ANHUI CONCH & 27.5 & & 24.0 & & 16 & 16 & 18 & 12 & 24.3 \\
\hline 2 & $\begin{array}{l}\text { SINOPEC SHANGHAI } \\
\text { PETROCHEMICAL }\end{array}$ & 12.4 & ${ }^{* *}$ & 14.2 & ${ }^{* *}$ & 17 & 20 & 22 & 24 & 8.3 \\
\hline 3 & ANGANG STEEL & 18.8 & **** & 14.6 & ${ }^{* *}$ & 11 & 11 & 17 & 15 & 19.1 \\
\hline 4 & $\begin{array}{l}\text { MAANSHAN IRON \& } \\
\text { STEEL }\end{array}$ & 18.3 & ${ }^{* * * *}$ & 15.9 & ${ }^{* *}$ & 20 & 21 & 23 & 21 & 10.4 \\
\hline 5 & JIANGXI COPPER & 13.9 & ** & 25.1 & ${ }^{* * *}$ & 18 & 14 & 12 & 11 & 24.8 \\
\hline
\end{tabular}

Remark: The rejection of $\mathrm{H0}: \mathrm{r}=0$ is remarked by ${ }^{* *}$ and ${ }^{* * *}$ at $5 \%$ and $1 \%$ sig. level, respectively. Pre: Pre-structural break period Jan 2004 Apr 2007. Post: Post-structural break February 2009 - Dec 2011. ICB\#: listed on SEHK and SHS on October 27, 2006.

Other co-integrated companies in different sectors also approved a stronger and more significant A- $\mathrm{H}$ - shares co-integration at $1 \%$ and $5 \%$ levels. The following table illustrated the listed companies with market capitalization exceeding HK\$1 billion in different sectors.

Table 4. Co-integrated companies by sectors

\begin{tabular}{|c|c|c|c|c|c|c|c|}
\hline & Name & Pre & & Pos & & $\begin{array}{l}\text { Mkt cap } \\
\text { (HK\$bn) }\end{array}$ & Sector \\
\hline DFE & Dongfang Elec & 15.1 & & 25.2 & (Fe & 6.5 & Capital Goods \\
\hline GZS & Guangzhou Shipyard & 8.6 & & 13.5 & ** & 2.5 & Capital Goods \\
\hline HKE & Hisense Kelon Electrical & 9.8 & & 23.1 & *** & 1.0 & Consumer Durables \\
\hline $\mathrm{CPC}$ & China Petrochem & 27.6 & ${ }^{* * *}$ & 21.6 & *** & 116.8 & Energy \\
\hline YCM & Yanzhou Coal Mining & 11.0 & * & 12.8 & ** & 23.6 & Energy \\
\hline TDB & Tsingtao Brew & 16.4 & $* * *$ & 47.3 & *** & 17.6 & Food Beverage \\
\hline BNS & Beijing North Star & 20.5 & $* * *$ & 26.7 & *** & 2.3 & Real Estate \\
\hline ZTE & ZTE & 16.1 & $* *$ & 25.8 & $* * *$ & 9.9 & Technology \\
\hline AIR & Air China & 12.7 & ** & 24.9 & *** & 22.0 & Transportation \\
\hline CSD & China Ship Dev & 16.3 & $* *$ & 14.1 & ** & 15.2 & Transportation \\
\hline JSE & Jiangsu Expressway & 34.7 & $* * *$ & 17.6 & $* * *$ & 8.3 & Transportation \\
\hline CEA & China East Air & 12.0 & * & 20.8 & *** & 7.5 & Transportation \\
\hline CSA & China South Air & 14.7 & ** & 12.7 & ** & 4.9 & Transportation \\
\hline SZE & Shenzhen Express & 12.5 & ** & 26.9 & *** & 2.9 & Transportation \\
\hline AHE & Anhui Express Way & 10.2 & & 18.0 & *** & 2.4 & Transportation \\
\hline HNP & Huaneng Power & 24.4 & $* * *$ & 27.5 & $* * *$ & 18.7 & Utilities \\
\hline HDP & Huadian Power & 7.5 & & 25.2 & $* * *$ & 4.3 & Utilities \\
\hline ICB & $\begin{array}{c}\text { Indust'l \& Commerc'l Bank of } \\
\text { China }\end{array}$ & 18.1 & $* * *$ & 12.1 & & 463.5 & Banks \\
\hline $\mathrm{BOC}$ & Bank of China & 16.8 & ${ }^{* * * *}$ & 18.4 & **** & 293.4 & Banks \\
\hline
\end{tabular}

Pre: Pre-structural break period Jan 2004-Apr 2007. Post: Post-structural break February 2009-Dec 2011. ICB\#: listed on SEHK and SHS on October 27, 2006.

In addition to market capitalization ranking, we also looked at other factors that may affect the trading activity of our basket of stocks co-listed in Hong Kong and Shanghai stock exchanges.

\section{Discussion and Conclusion}

In modern era, China has adopted an open-door policy in economy to strengthen its influence and connection to the world. Hong Kong, being one of the top financial markets globally, provided an ideal platform for Chinese firms to raise capital by listing their shares at the Hong Kong Stock Exchanges (SEHK). As of end of 2008, more than 41 Chinese companies dually listed in both Hong Kong and Shanghai stock exchanges. Given the closely economic and political relationship between Hong Kong and Mainland China, Su, Chong and Yan (2007) provided evidence that supported the presence of co-integration of the dually listed shares performance from 2002 to 2004. 
On the backdrop of the global financial turmoil in 2007 and 2008, this paper re-evaluated the co-integration of the major dually listed shares performance, employing the VECM and Johansen Trace test, from a different perspective at a different timeframe from January 2004 to December 2011, excluding the structural break period April 2007 to January 2009.

In our study, the co-integration analysis of $\mathrm{A}$ and $\mathrm{H}$ shares showed the price performance of the major Chinese firms in Shanghai stock exchanges and Hong Kong stock exchanges were becoming more co-integrated, especially after the financial breakout. In our universe, 33 out of 35 shares reported a significant and stronger co-integration among A- H- shares performance, according to the Johansen trace test.

This may be attributed to the rapid economic reform in China and its financial markets have been developing fast, and hence further approved that the public companies, with identical business models and equity valuations, listing in different stock exchanges showed to have the same price performance in a long run.

\section{Acknowledgements}

The authors gratefully acknowledge the financial support from the Research Committee of the Hong Kong Polytechnic University.

\section{References}

Akaike, H. (1974). A new look at the statistical model identification. IEEE Transactions on Automatic Control, 19(6), 716-723. http://dx.doi.org/10.1109/TAC.1974.1100705

Corhay, A., Tourani, R. A., \& Urbain, J. P. (1993). Common stochastic trends in European stock markets. Economics Letters, 42(4), 385-390. http://dx.doi.org/10.1016/0165-1765(93)90090-Y

Engle, R. F., \& Granger, C. W. J. (1987). Co-Integration and error correction: Representation, estimation, and testing. Econometrica, 55(2), 251. http://dx.doi.org/10.2307/1913236

Granger, C. W. J. (1981). Some properties of time series data and their use in econometric model specification. Journal of Econometrics, 16(1), 121-130. http://dx.doi.org/10.1016/0304-4076(81)90079-8

Hannan, E. J., \& Quinn, B. G. (1979). The determination of the order of an autoregression. Journal of the Royal Statistical Society, B41, 190-195.

Johansen, S. (1988). Statistical analysis of cointegration vectors. Journal of Economic Dynamics and Control, 12(2-3), 231-254. http://dx.doi.org/10.1016/0165-1889(88)90041-3

Johansen, S. (1994). The role of the constant and linear terms in cointegration analysis of nonstationary variables. Econometric Reviews, 13(2), 205-229. http://dx.doi.org/10.1080/07474939408800284

Johansen, S. (1995). Likelihood-based inference in cointegrated vector autoregressive models. Oxford: Oxford University Press. http://dx.doi.org/10.1093/0198774508.001.0001

Kasa, K. (1992). Common stochastic trends in international stock markets. Journal of Monetary Economics, 29(1), 95-124. http://dx.doi.org/10.1016/0304-3932(92)90025-W

Kratzig, M., \& Lutkepohl, H. (2004). Applied time series econometrics. Cambridge: Cambridge University Press.

Lee, T. H., \& Tse, Y. (1996). Cointegration tests with conditional heteroskedasticity. Journal of Econometrics, 73(2), 401-410. http://dx.doi.org/10.1016/S0304-4076(95)01745-3

MacDonald, R., \& Talor, M. P. (1991). Exchange rates, policy convergence, and the european monetary system. The Review of Economics and Statistics, 73(3), 553-558. http://dx.doi.org/10.2307/2109585

Perron, P., \& Yabu, T. (2009). Testing for shifts in trend with an integrated or stationary noise component. Journal of Business \& Economic Statistics, 27(3), 369-396. http://dx.doi.org/10.1198/jbes.2009.07268

Schwarz, G. (1978). Estimating the dimension of a model. The Annals of Statistics, 6(2), 461-464. http://dx.doi.org/10.1214/aos/1176344136

Su, Q., Chong, T. T. L., \& Yan, I. K. M. (2007). On the convergence of the Chinese and Hong Kong stock markets: A cointegration analysis of the A and H shares. Applied Financial Economics, 17(16), 1349-1357. http://dx.doi.org/10.1080/09603100600993760

Taylor, M. P., \& Tonks, I. (1989). The internationalisation of stock markets and the abolition of U.K. exchange control. The Review of Economics Statistics, 71(2), 332-336. http://dx.doi.org/10.2307/1926980

Toda, H. Y., \& Phillips, P. C. B. (1993). Vector autoregressions and causality. Econometrica, 61(6), 1367-1393. 
http://dx.doi.org/10.2307/2951647

\section{Copyrights}

Copyright for this article is retained by the author(s), with first publication rights granted to the journal.

This is an open-access article distributed under the terms and conditions of the Creative Commons Attribution license (http://creativecommons.org/licenses/by/3.0/). 